Tenório et al., 2018

Volume 2 Issue 2, pp.51-65

Date of Publication: 14th July, 2018

DOI-https://dx.doi.org/10.20319/pijtel.2018.22.5165

This paper can be cited as: Tenório, M. M., Lopes, R. P., Góis, L. A., E Junior, G. D. (2018). Influence of Gamification on Khan Academy in Brazilian High School. PUPIL: International Journal of Teaching,

Education and Learning, 2(2) 51-65.

This work is licensed under the Creative Commons Attribution-Non-commercial 4.0 International License. To view a copy of this license, visit http://creativecommons.org/licenses/by-nc/4.0/ or send a letter to Creative Commons, PO Box 1866, Mountain View, CA 94042, USA.

\title{
INFLUENCE OF GAMIFICATION ON KHAN ACADEMY IN BRAZILIAN HIGH SCHOOL
}

\author{
Marcos Mincov Tenório \\ Programa de Pós Graduação em Ensino de Ciência e Tecnologia, Federal University of \\ Technology - Paraná (UTFPR), Ponta Grossa, Brazil \\ mmtenorio@gmail.com \\ Rui Pedro Lopes \\ Departamento de Informática, Polytechnic Institute of Bragança (IPB), Bragança, Portugal \\ rplopes@ipb \\ Lourival Aparecido de Góis \\ Departamento de Informática, Federal University of Technology - Paraná (UTFPR), \\ Ponta Grossa, Brazil \\ gois@utfpr.edu.br \\ Guataçara dos Santos Junior \\ Programa de Pós Graduação em Ensino de Ciência e Tecnologia, Federal University of \\ Technology - Paraná (UTFPR), Ponta Grossa, Brazil \\ guata@utfpr.edu.br
}

\begin{abstract}
This article approaches current pedagogical practices in the national guidelines, related to the use of information and communication technologies. We report the actions taken in a compulsory curricular internship of the bachelor's degree in informatics of the UTFPRFrancisco Beltrão Campus. The internship student performs observation and experiment inside a first-year high school classroom and suggest the use of an e-learning tool to support learning,
\end{abstract}


reinforce classroom concepts and motivate students to perform extra classroom activities. Gamification technique was suggested seeking to increase students' motivation, engagement and commitment. To address this issue, the e-learning system of Khan Academy was selected and their structure and functions was studied, serving as technological support for gamification actions. An experiment was proposed to obtain results regarding the Khan Academy and gamification usage inside a classroom environment. When applied, Khan Academy has proved to be a promising tool regarding new opportunities and ways of engaging student especially with the built-in gamified structures. Yet, the role of teachers in motivating students to perform extraclassroom activities in the pursuit of knowledge remains crucial, even with the use of online tools and gamification technique.

\section{Keywords}

Computers in Education, E-Learning, Khan Academy, Gamification, Internship Program

\section{Introduction}

The Bachelor's Degree in Informatics of the UTFPR-Francisco Beltrão Campus, has in its Political Pedagogical Plan, actions of understanding and intervention in the teaching-learning process. It also makes use of or develops technological innovations directed to the activities of the obligatory curricular internship. This enables them, as teachers in formation, to be able to meet the needs of society.

The phase of observation of the compulsory curricular internship had the benefit of contributing to the expansion of the student's knowledge regarding academic practices, so that these students explore concepts learned in classrooms.

The observations approached the qualitative formation with direct benefits for teaching, enabling to generate knowledge and contributions on the practice of pedagogical actions and school management without affecting the well-being of the participant and the group, or collectively. It also showed that public school teachers are concerned with students who are regularly exposed to interferences in technological entertainments without specific or general school content. This dispersion into the classroom becomes the second most prominent problem in the institution - "...school activities do not motivate students outside the walls..." observed by one of the teachers. At various times of observation, students reported "...school activities do not generate involvement...", discouraging them from completing homework assignments since they are not technologically attractive (Lee \& Doh, 2012). 
In order to address this problem of student's daily life, it was hypothesized that the use of an e-learning tool to support learning could become a reinforcement unit to contents seen in the classroom (Franca \& Reategui, 2013), motivating students to perform the extra classroom activities through the gamification technique.

In this paper we suggest that educational environments can be rebuilt through extra-

classroom activities by applying the gamified approach to engage the student with the extraclassroom tasks. An e-learning pedagogical tool as KhanAcademy, and the application of gamification technique was studied. Finally, to analyze the results from this approach we design an experimental study inside a classroom environment.

\section{Literature Review}

\subsection{From E-Learning to Gamification}

The difference between e-learning and traditional learning environments relies mainly in the medium. In a e-learning perspective the learning provider is separated from the learner by cyberspace and such systems are tools that provide these connections (Dečman, 2015).

However, even fulfilling these requirements, several e-learning tools still shows problems derived to their practical application. Moodle, for example, was analyzed by (Santana, Neto \& Costa, 2014), where the authors observed the components of Moodle and verified: (a) if they were being used; (b) which were most used; (c) which were useful for the teaching-learning process; and (d) if they influenced the student's performance. The authors found that most of the components were underutilized, not significantly influencing the student's performance and proving to be a content storage system.

To overcome this issue, authors (Erenli, 2012) proposed alternative ways, the playful ones, to involve the user with the teaching tools. For (Halvorsen, 2013), the learning technique known as Gamification is the approach that is getting highlighted recently with students in extraclassroom activities and is proven to be a promising tool regarding students' involvement in learning environments.

Gamification is an approach that seeks to increase motivation, engagement and commitment, using game elements and mechanisms in "non-game" contexts (Deterding, Dixon, Khaled \& Nacke, 2011). Gamification works directly with the student's motivation, being of two types: extrinsic and intrinsic (Domínguez et al., 2013). The author still suggest that extrinsic motivation is concerned with methods of classifications, levels, scoring, medals, rewards, and 
missions; and intrinsic motivation has a strong appeal to game design and works with the elements that generate greater emotional engagement where the user decides where and when to act. Some examples are: altruism, competition, cooperation, companionship, love or aggression (Domínguez et al., 2013).

Preliminary studies have shown that gamification allows a marked improvement in the student's abilities and competences (Hanus \& Fox, 2015). For extra-classroom activities, gamification would act as a mediating unit, bringing the student closer to the digital environment present in his daily life, to the contents addressed in the classroom by the teachers (Falcão, Leite \& Tenório, 2014).

\subsection{Khan Academy}

KhanAcademy (Khan Academy, 2017) is a free e-learning tool to support school teaching in several languages. It offers the process of reinforcement in activities and homework but has gamification as its differential. KhanAcademy usage is used supporting the publication of the Brazilian Law of Guidelines and Bases (LDB) no. 9394/96 and contemplate the National Parameters of Secondary Education (PCNEM) that instructed changes in the design of activities, such as how to systematize classroom learning, to prepare students for new content and deepen their knowledge (Brasil, 2000):

"[...] with the advent of what is called a post-industrial society, the dissemination of informational technologies in products and services, the increasing complexity of individual and collective equipment, and the need for ever more elaborate knowledge for social and productive life, the technologies need to find their own space in regular school learning, similar to what happened to the sciences many decades ago, and should be seen as a process, not simply as a product" (Brasil, 2000).

The insertion of this type of e-learning in schooling reinforcement, allows to approach several activities in different scenarios. As ICT, KhanAcademy uses technologies to offer a targeted planning to meet educational objectives and is not limited to the use of modern passive transmission/reproduction equipment of traditional teaching (Silva, 2008). It also extends the possibilities of access to learning, allowing the student and teacher to maintain contact with the subject in an asynchronous and geographically distant way. In addition, it presents itself as a virtual space where students and teachers interact on the content of the course, prepare papers, engage in discussion groups and learn in collaboration through forums, chats, file transfers, among others (Romero, Ventura \& García, 2008). For the school, KhanAcademy supports 
learning to be contemplated in the curriculum and in the pedagogical work as it considers its use appropriately as a skill. For the teacher, KhanAcademy acts in continuing education and classroom support. For students, called digital natives (Prensky, 2001), their differentiated way of learning is seen by the use of KhanAcademy as an advance in relation to the use of traditional ICT in education, aptly fomenting its use, but still little articulated with the reality of schools, with many advances still needed to achieve an ideal practice.

KhanAcademy also contemplates countless strands fulfilling several roles. For the observational phase, the main characteristics necessary for the school under observation are:

- Mediation: Expands teaching and learning by providing virtual contact in the classroom, giving the student a friendly learning environment that motivates him to observe and reinforce the theoretical content of the classroom (Franca \& Reategui, 2013).

- Evaluation: Through the analysis of the exercises, the teacher can detect the difficulties of each student and build pedagogical strategies to reinforce these points (Leite et al., 2015). If it is an extra-classroom activity, then it acts as a social function when approaching the family and the school, as it allows the family to accompany the student's learning and can contribute and even interfere in this activity.

KhanAcademy was designed to be dynamic in the face of recent curricular reforms, compromising to cover all areas of knowledge without moving the school away from the student's reality. In this way, the issue of the interrelationship of the subjects in their different areas of knowledge with mediation and articulation with informational technology and ICTs emerge in a space for access to information in the different areas of school learning. Prensky addresses this problem by stating that the new generations are already born and grow in a digital and computerized world - known as "digital natives" - who already live with new technologies, experience experiences and learn through digital teaching methods such as computer, internet, video game and mobile (Prensky, 2001). Its purpose is to promote the fight against digital exclusion, as shown in another document:

"[...] On the other hand, informational and communicational technologies have modified and continue to modify people's behavior and these changes must be incorporated and processed by the school to avoid a new form of exclusion, the digital one. [...]” (Brasil, 2000).

The digital and attractive scenario of KhanAcademy contemplates the last reformulation of the National Curricular Guidelines of 2013, where: 
"[...] informational and communicational technologies are part of a continuous development of technologies, starting with chalk and books, all of which can support and enrich learning. This distance needs to be overcome by approximating the technological resources of information and communication, stimulating the children with new teaching didactic methods." (Brasil, 2000).

This counterpart is in line with the tool of laws and guidelines for more than 15 years of existence (LDB and PCNEMs of 2000). General national curriculum guidelines for Basic Education in 2013 indicate such situation:

"[...] while the school attaches itself to the characteristics of traditional methodologies, with regard to teaching and learning as separately designed actions, the characteristics of its students require other processes and procedures in which to learn, teach, research, investigate and evaluate, occur in an inseparable way. They learn to receive information quickly, enjoy the parallel process, multi-task, prefer to make their charts before reading the text, while teachers believe that they follow the digital age just because they type and print texts and have e-mails, not realizing that students were born in the digital age." (Brasil, 2000).

The Portuguese language version has educational resources for students and teachers in the areas of Mathematics, Chemistry, Physics, Biology, Medicine, Economics and Computing. The main features are video lessons with tips and explanations, according to Figure 1.

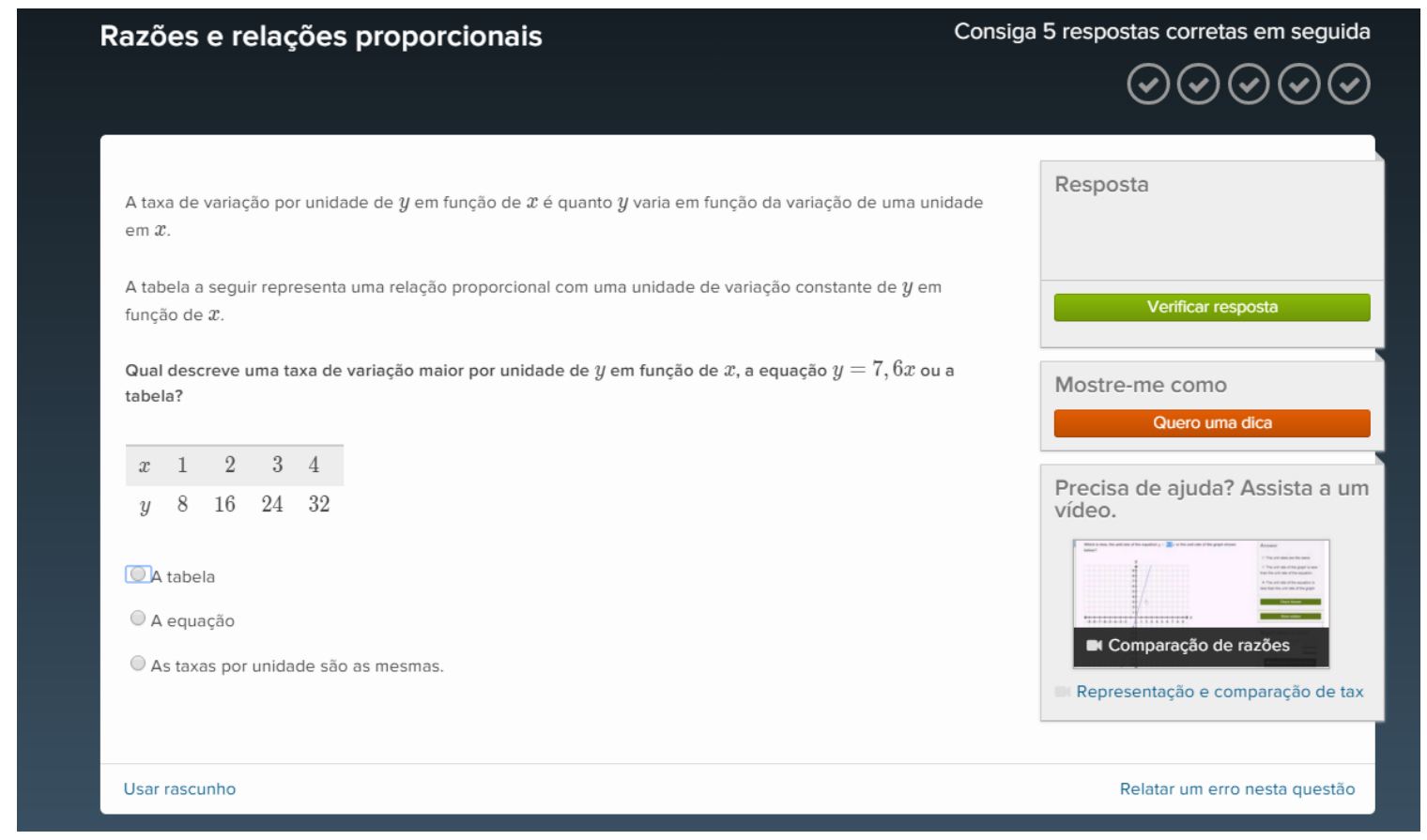

Figure 1: Activities realization screen (KhanAcademy Screenshot). 
From the perspective of Gamification, it is possible to verify:

- Missions, which suggests the student to watch a video lesson of the subject always before a cycle of activities;

- Scoring System, denominated of points of energy, that holds the attention of the student, encouraging him to continue in the tool. This motivates the student to watch the whole video lesson and the system assigns him power points.

- Medals, representing another way to compensate and encourage the student to complete school practice actions, such as studying daily, watching video lessons, participating in discussion groups, among others.

When dealing with behavioral actions, the repetitions by cognition work well as a form of support and fixation to the learning occurred in the classroom. The system is structured in objective cycle-segmented activities with computer-mediated learning methods, where the student must guess a quantity followed by questions to complete that cycle, see Figure 1. For contents involving the area of exact, Kenski found that the fixation was more successful in classroom learning (Kenski, 2007).

Under the Smart Tutoring template, the tool offers suggestions for activities where the student presented the most difficulty. The difficulties are signalized by activities that the student performed, but needed tips or explanation during the video lesson, if he exceeded the time limit to perform the activity and the total useful time that the student remained in the system performing activities, watching video classes or on some project.

The suggestions are in the form of recommendation by intervention, which is a practice of intelligent tutor systems where the KhanAcademy system can recommend activities or missions to a specific student, and signals to the teacher that skill necessary to be practiced by the student.

\section{Experiment}

\subsection{Setting and Subjects}

The experimental study was carried out at Cristo Rei State College, located in the city of Francisco Beltrão, Brazil. The application of the tool was carried out with students participating in the first year of high school, regularly enrolled college. 
The inclusion criterion was students with a higher degree of difficulty in the mathematics subject within the contents that were being studied at the moment: arithmetic and geometric progression and linear functions. The exclusion criterion was defined as not having access to KhanAcademy outside the classroom. Satisfying the criteria, 10 students formed the research participants group.

\subsection{Software}

KhanAcademy, a gamified e-learning tool was used to perform the experimental study. In the software a profile was created for the access of the observers and a virtual class entitled "Mathematics - Cristo Rei 1st A". Figure 2 shows the initial interface of the tool already modeled, for reasons of confidentiality, the user names of the students are unfocused.

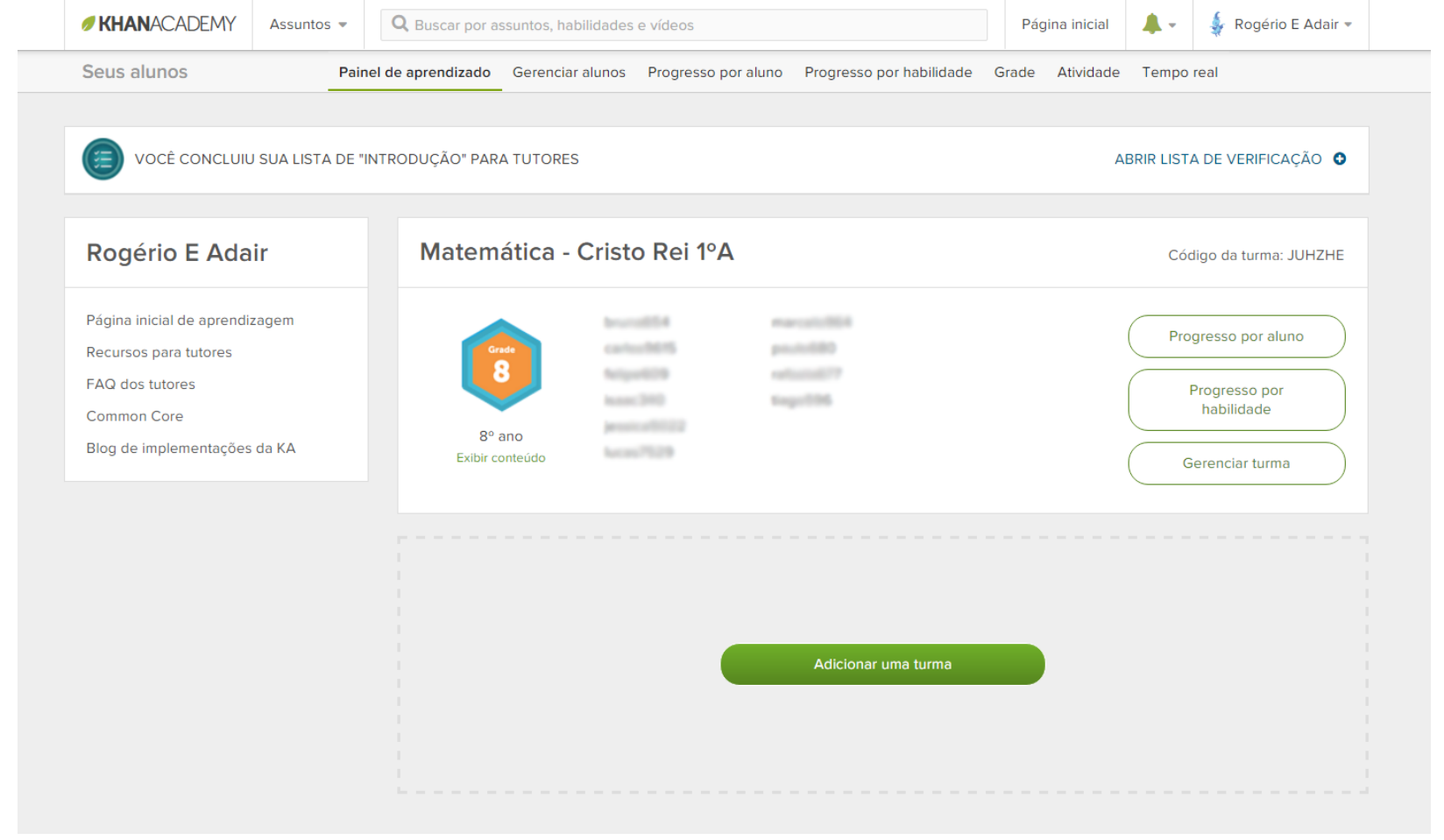

Figure 2: Home screen of the KhanAcademy system modeled (KhanAcademy Screenshot).

\subsection{Application}

The selected students went to the laboratory where the first registration was made in the system and the presentation of the tool was performed through the accomplishment of an activity. After the presentation of the tool, it was proposed to the students to finish the mission term gamified of KhanAcademy - at home. It is worth mentioning that it was informed in case of doubts the student graduating from the compulsory internship would be available for a period of 10 days in the computer lab providing explanations and accompanying the activities. 
The teacher responsible for supervising this stage of observation of the internship in the college followed the whole execution of the activity. The mission of the class was chosen: contents of Mathematics, related to linear functions and equations.

\subsection{Data collection and analysis}

In order to find out the influence of KhanAcademy in students, several data were retrieved from KhanAcademy software logs and discipline results.

To perform this study we collect students' data, especially student progress and actions taken inside the e-learning environment. Correlations were also performed to understand the relationship between performance and workload variables.

\section{Results}

The presentation of the tool generated expectations in the students. All the students seemed enthusiastic about a tool that would aid them in extra-classroom activities. The enthusiasm of the students was measured in a questionnaire with closed questions. The result is shown in Figure 3.

\section{Students' expectation}

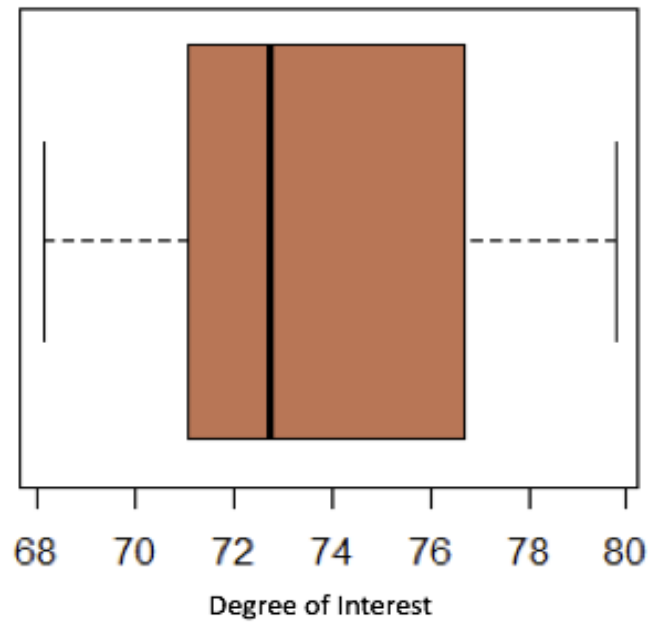

Figure 3: Expectation in \% of the students to the use of the tool.

The boxplot chart shows that approximately $90 \%$ of students were enthusiastic about the tool and its operational features of immediate feedback and invigorating gamed layout. Table 1 represents the values collected.

Table 1: Summary of the set of values of the students' expectation

\begin{tabular}{|c|c|c|c|c|c|}
\hline Min. & $\mathbf{1}^{\text {st }}$ Qua. & Medium & Average & $\mathbf{3}^{\text {rd }}$ Qua. & Max. \\
\hline 68.13 & 71.38 & 72.76 & 73.60 & 76.31 & 79.76 \\
\hline
\end{tabular}


Obtaining an expectation of mean of 73.60 and standard deviation of 3.4714 , it was possible to compute the probability of obtaining that an index of interest higher than $70 \%$ would reach $59.87 \%$ of the students.

Parallel to the evaluation period, for each student assessed in other subjects was measured. Figure 4 shows the increased workload that each student received that week with other teachers who use traditional methods.

\section{Extra-classroom workload}

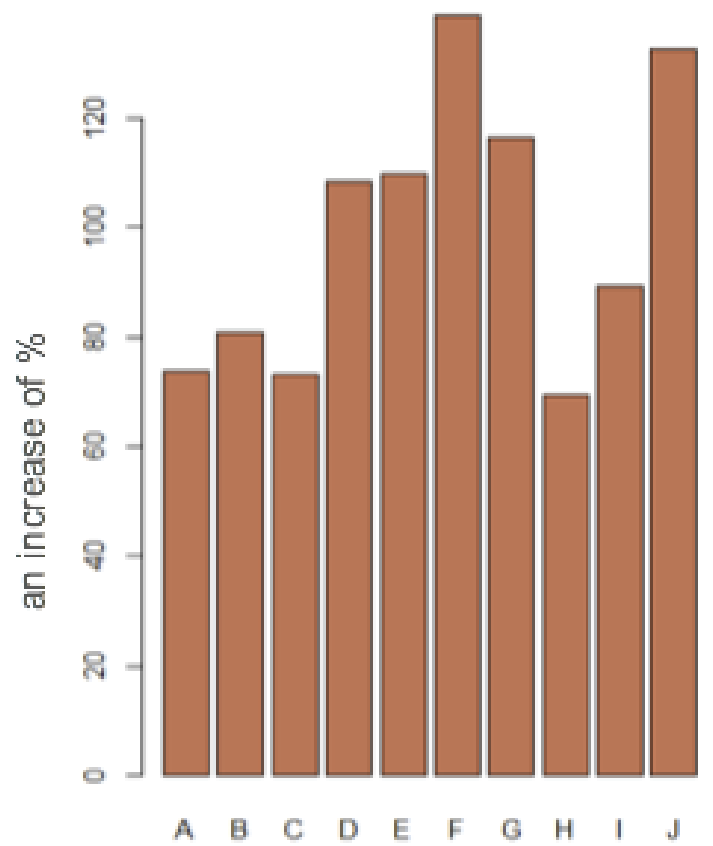

Students

Figure 4: Bar chart showing a specific increase in the activities of each student

The workload was measured on a scale of $0 \%$ to $145 \%$. The amplitude of the chart above shows a value of $69.22 \%$. If we look at the set of data referring to the increase of school activities, the activities had a height of $98.80 \%$ and this significantly affected the performance of students, overwhelming the e-learning environment.

The reflection of this probability is in the data extracted from the tool, where it points the progression of the students during this period of execution of the activities with KhanAcademy. It presents that, in a general way, the students only realized $10 \%$ of the activities at home, using the effective time of 33 minutes in the system. There were also other participations, however atypical and were not computed.

The practicality of the tool allows interesting data regarding student progress to be available to the teacher. Figure 5 shows the skills practiced by the student who acted most in the 
tool. In this figure it is possible to notice that the tool already provides some indications to the teacher, for example, this student needs to practice more activities of cubic roots.

\begin{tabular}{|c|c|c|c|c|c|c|c|}
\hline \multicolumn{5}{|l|}{ 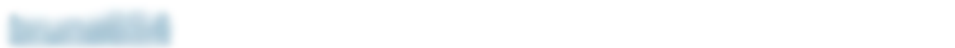 } & \multicolumn{3}{|c|}{ ๑ Fazer uma recomendaçã } \\
\hline Recomendações & Vídeos & Medalhas & Atividade & Foco & & & \\
\hline \multicolumn{8}{|l|}{ Progresso total de $8^{\circ}$ ano } \\
\hline \multicolumn{8}{|c|}{0 habilidades dominadas } \\
\hline \multicolumn{8}{|c|}{0 habilidades do nível 2} \\
\hline \multicolumn{8}{|c|}{5 habilidades do nível 1} \\
\hline \multicolumn{8}{|c|}{2 habilidades praticadas } \\
\hline \multicolumn{8}{|c|}{108 habilidades não iniciadas } \\
\hline \multicolumn{5}{|l|}{ Atividade de:Últimos 7 dias } & \multicolumn{3}{|c|}{$\square$ Exibir apenas habilidades praticadas } \\
\hline \multicolumn{8}{|l|}{ - FUNDAMENTOS DA MISSÃO } \\
\hline \multicolumn{5}{|l|}{ Habilidade } & Nível & Perguntas & ○ \\
\hline \multicolumn{5}{|l|}{ Divisão por 2 algarismos } & 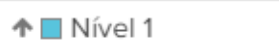 & 1 & - \\
\hline \multicolumn{5}{|c|}{ Multiplicação e divisão de números negativos } & $\uparrow \square$ Nível 1 & 1 & - \\
\hline \multicolumn{5}{|c|}{ Multiplicação de números de vários algarismos } & $\uparrow \square$ Nivel 1 & 1 & - \\
\hline \multicolumn{5}{|c|}{ Ângulos opostos pelo vértice } & $\uparrow \square$ Nível 1 & 1 & - \\
\hline \multicolumn{5}{|c|}{ Ângulos complementares e suplementares } & 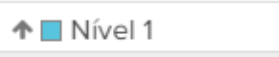 & 1 & - \\
\hline \multicolumn{8}{|l|}{ HABILIDADES ADICIONAIS } \\
\hline \multicolumn{5}{|l|}{ Habilidade } & Nível & Perguntas & ○ \\
\hline \multicolumn{5}{|c|}{ Raízes quadradas de quadrados perfeitos } & $\uparrow \square$ Praticado & 1 & - \\
\hline \multicolumn{5}{|c|}{ Raízes cúbicas } & $\square$ Precisa praticar & 3 & 2 \\
\hline \multicolumn{5}{|l|}{ Resolução de funções } & $\uparrow \square$ Praticado & 2 & 1 \\
\hline
\end{tabular}

Figure 5: Student's progress (KhanAcademy Screenshot).

Additionally, Pearson's correlation coefficient was used to understand to a certain extent, measure and evaluate if the two variables low yield and excess of tasks would change together (to be associated to a proportional change in the other variable). See Figure 6.

Although the correlation does not imply cause, it pointed to a probable explanation, that the traditional type of works influenced the low performance of the students. 


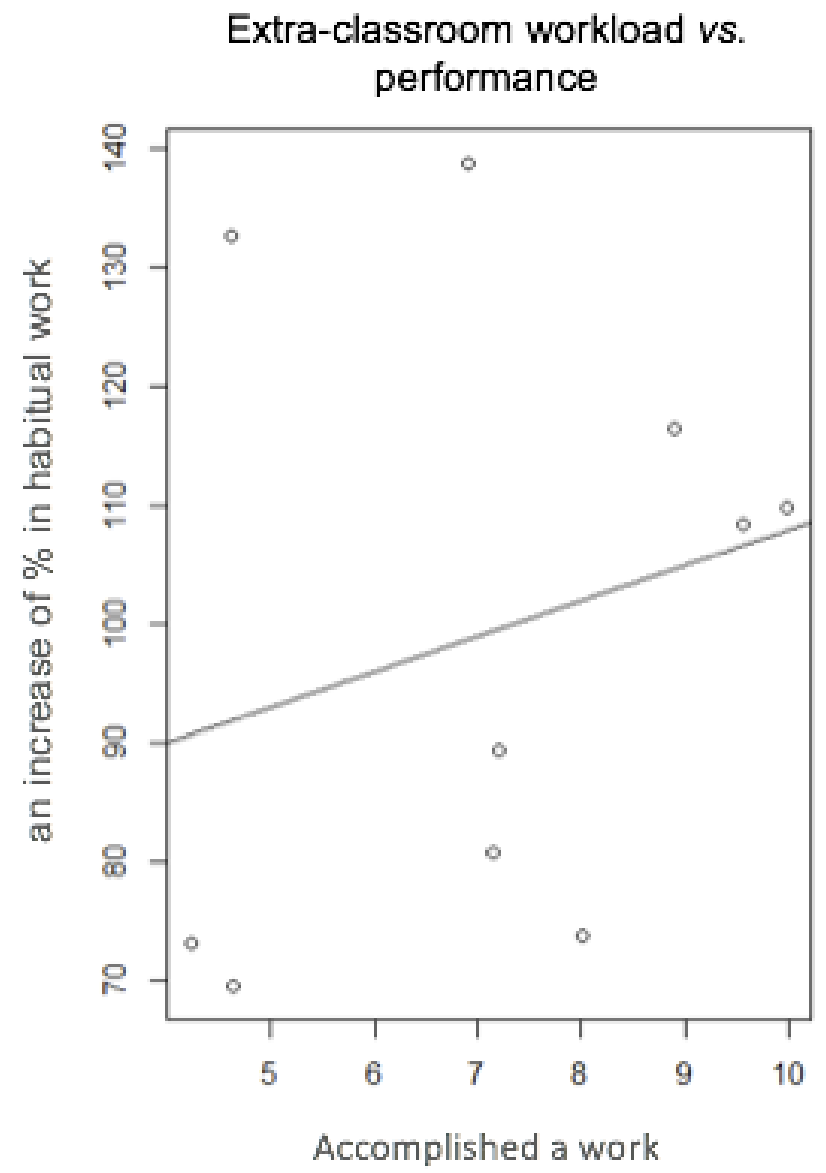

Figure 6: Pearson's correlation between two variables

\section{Conclusions}

The KhanAcademy tool has proved to be very promising by bringing new opportunities and ways of engaging the student with the activities and at the same time providing precious data for the teacher. Although the application of the activity resulted in a low participation rate, the explanation is in the fact that the school year differed from the normal one, given that the State teachers were on strike for 46 days, leading to re-adjustments in the school calendar resulting in the students having an increase in the daily class hours from 5 to 6 classes. This resulted in a greater burden of work through time-consuming traditional methods, costing time for KhanAcademy. Yet it is not possible to conclude precipitously that it did not live up to expectations or that the use of technology in education does not bring improvements.

Some problems have been identified, such as, the lack of motivation and interest of the students when it relates to the excess of traditional study in non-related extra-classroom activities. The intervention of the proposal in presenting the application of the KhanAcademy 
system to act as a tool to support teaching, generated expectations in the teacher responsible for the subject and started to show more interest, since it is possible to work with the information provided with immediate feedback/progress.

The cultural and behavioral changes of students and especially of teachers, is not something that can be done in a short period of time and with only a single application of the pedagogic tool. The results showed that the greatest motivator and responsible for the student's learning is the teacher, and that technology can be used as a tool which has great potential to serve and assist the teacher in the teaching-learning process.

Education in this new reality of the digital age requires changes. The student profile is no longer the same as a few years ago and, the school and teachers have stopped following these changes. Students are in a dilemma whether technologies should be harnessed by the school and teachers to increase education and approach the student, or if traditionalism will continue to govern in classrooms. Of course, the solution to problems involving technology in education goes well beyond the qualification of the teacher, since, it does not make sense to have a qualified teacher and not give him an adequate pedagogical preparation or not have the technological resources available.

The results point to a resolution in the change of the school and in the approach of the use of technologies in education, being necessary the commitment of all the instances of society. In order for learning to be in accordance with the different social realities, the teacher, as the principal involved in this process must seek alternatives to bring the student closer to the school and motivate him to seek knowledge. For this, it is fundamental to use the technologies present in the student's everyday life.

\section{References}

Brasil. Parâmetros Curriculares Nacionais Ensino Médio (2000).

Dečman, M. (2015). Modeling the acceptance of e-learning in mandatory environments of higher education: The influence of previous education and gender. Computers in Human Behavior, 49, 272-281. https://doi.org/10.1016/j.chb.2015.03.022

Deterding, S., Dixon, D., Khaled, R., \& Nacke, L. (2011). From Game Design Elements to Gamefulness: Defining 'Gamification'. In Proceedings of the 15th International 
Academic MindTrek Conference: Envisioning Future Media Environments (pp. 9-15).

New York, NY, USA: ACM. https://doi.org/10.1145/2181037.2181040

Domínguez, A., Saenz-de-Navarrete, J., de-Marcos, L., Fernández-Sanz, L., Pagés, C., \&

Martínez-Herráiz, J.-J. (2013). Gamifying learning experiences: Practical implications

and outcomes. Computers \& Education, 63, 380-392.

https://doi.org/10.1016/j.compedu.2012.12.020

Erenli, K. (2013). The Impact of Gamification - Recommending Education Scenarios. International Journal of Emerging Technologies in Learning (IJET), 8(S1), 15-21. https://doi.org/10.3991/ijet.v8iS1.2320

Falcão, A. P., Leite, M. D., \& Tenório, M. M. (2014). Ferramenta de apoio ao ensino presencial utilizando gamificação e design de jogos. (p. 526). https://doi.org/10.5753/cbie.sbie.2014.526

Franca, R. M., \& Reategui, E. B. (2013). SMILE-BR: aplicação de conceitos de gamificação em um ambiente de aprendizagem baseado em questionamento. Anais do Simpósio Brasileiro de Informática na Educação, 24(1). https://doi.org/10.5753/CBIE.SBIE.2013.366

Halvorsen, M. (2013, November). The use of gamification in learning applications. The University of Bergen, Bergen.

Hanus, M. D., \& Fox, J. (2015). Assessing the effects of gamification in the classroom: A longitudinal study on intrinsic motivation, social comparison, satisfaction, effort, and academic performance. Computers \& Education, 80, 152-161. https://doi.org/10.1016/j.compedu.2014.08.019

Kenski, V. M. (2007). Educação E Tecnologias. Papirus Editora.

Khan Academy. (n.d.). Retrieved 21 November 2017, from http://www.khanacademy.org

Lee, H., \& Doh, Y. Y. (2012). A Study on the Relationship between Educational Achievement and Emotional Engagement in a Gameful Interface for Video Lecture Systems. In 2012 International Symposium on Ubiquitous Virtual Reality (ISUVR) (pp. 34-37). https://doi.org/10.1109/ISUVR.2012.21

Leite, M., Marczal, D., Krynski, E. M., Pimentel, A., Direne, A., \& Reinaldo, F. (2015). Otimizando o processo de Ensino e Aprendizagem com a Arquitetura para Desenvolvimento de Objetos de Aprendizagem - ADOA (p. 1002). https://doi.org/10.5753/cbie.sbie.2015.1002 
Prensky, M. (2001). Digital natives, digital immigrants Part 1. On The Horizon, 9(5), 1-6. https://doi.org/10.1108/10748120110424843 https://doi.org/10.1108/1074812011042481 $\underline{6}$

Romero, C., Ventura, S., \& García, E. (2008). Data Mining in Course Management Systems: Moodle Case Study and Tutorial. Comput. Educ., 51(1), 368384. https://doi.org/10.1016/j.compedu.2007.05.016

Santana, M. A., Neto, B. F. dos S., \& Costa, E. de B. (2014). Avaliando o Uso das Ferramentas Educacionais no Ambiente Virtual de Aprendizagem Moodle. Anais do Simpósio Brasileiro de Informática na Educação, 25(1), 278-287. https://doi.org/10.5753/cbie.sbie.2014.278

Silva, M. (2008). Internet na educação e inclusão social na era digital, na sociedade da informação e na cibercultura. Rio de Janeiro. 